\title{
Implications of GST on Indian Banking Sector
}

\author{
Pukhraj Paul, Vikram Sandhu, Heena Atwal
}

\begin{abstract}
The most vital sector that contributes 7.7 per cent to GDP in India is the banking sector. The important scenario was the introduction of Goods and Service Tax and its implication in Indian Banking Sector. GST was implemented by Government in India on 1st July, 2017 which changed the operational efficiency of banking sector than before. This present study aims to study the significant impact of GST on banking sector and the challenges imposed by the implementation of GST. This study also attempts to study the effect of GST on customer.
\end{abstract}

Keywords: Taxation, Goods and Service tax (GST), Indirect tax, Banking Sector, Government Policy.

\section{INTRODUCTION}

Indian Banking sector and tax system had lower productivity and misallocation of resources in terms of international trade, economic growth and development of economy as a whole. Therefore, this needed a replacement of existing taxation system with new taxation system of goods and services with the below mentioned reasons:

- The incidence of tax lies on primary consumption.

- Optimum use of efficiency in case of Indian system and its equity.

- Zero export of taxation across tax jurisdiction.

- Indian market should be under one umbrella.

- Cooperative federalism enhancement.

According to Indian Constitution's [GST India com,2016] new article number 366(12 A) defined GST as any tax levied on supply of goods \& services or both except the taxes levied on supply of liquor or alcohol. It is a comprehensive tax on sale, consumption and manufacture of goods \& services nationally.

\section{OBJECTIVES OF THE STUDY}

The present research is undertaken based on the following major objectives:

1. To measure the change in banking sector after implementation of GST.

2. To analyze the major challenges being faced by the banks in the implementation of GST GST on banks and its customers.

Revised Manuscript Received on November 11, 2019.

* Correspondence Author

Pukhraj Paul, Assistant Professor, University Business School, Guru Nanak Dev University, Amritsar. Punjab. India.

Dr.Vikram Sandhu, Assistant Professor, University Business School, Guru Nanak Dev University, Amritsar. Punjab. India.

Dr. Heena Atwal, Assistant Professor, Department of Basic and Applied Sciences, Punjabi University, Patiala. Punjab. India.
3. To find out the relative advantages and disadvantages of

\section{RESEARCH METHODOLOGY}

Technique used in this research paper is exploratory research. The data collected for this paper is collected from is secondary data. This data is collected from various statistical data websites and reports of Indian Government such as GST council (gstcouncil.gov.in), newspaper reports, journal papers and from magazine articles on GST.

\section{IMPLICATIONS OF GST ON BANKING SECTOR}

The GST model law and its framework did not allowed a lot of benefits to banks. It did not understand the consideration to the type of transactions that take place continuously and on a wider scale. The various impacts as well as challenges that are related to the provisions of the Model GST Law have been enunciated further here.

Before and after comparison of banking services

I. BEFORE GST IMPLEMENTATION

- No Service Tax was levied on income earned through Interest Income.

- Commission income gained/earned was liable for Service tax only.

- Brokerage Income gained/earned was liable for Service tax.

- Agency Services gained/earned by banks was liable for Service tax.

- Portfolio Management Service was liable for Service tax.

- Credit as well as Debit charges were liable for Service tax.

- Income earned by way of penalties, retention charges were also liable for payment of Service tax.

- Inter sale or purchase of Foreign Currency amongst bank or authorized dealers of foreign exchange was not liable for Service tax.

- Services by the Reserve Bank were not liable for Service tax.

- Under CENVAT credit rules of India, banks have the option that they can pay for every month such a amount that is equal to 50 per cent of CENVAT credit gained for input and input services in that particular month. The CENVAT credit can be availed if there are no reversal conditions.

\section{AFTER GST IMPLEMENTATION}

- Before implementation of GST 15 per cent Service tax rate was followed, after GST implementation it increased to 18 per cent tax rate.

- Centralized registration is not possible under GST regime. Banks need to register separately if they open branch for every state (section 22 of CGST Act). They can have only one registration for multiple branches in one state.

- An annual return and three times a monthly return are to be furnished by the bank.

- As per definition of Service provided by section 2(102), Service means anything that is other than goods. By interpreting it in that way,

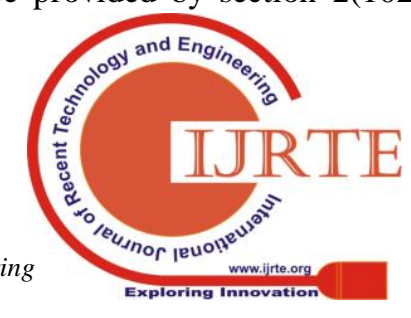


interest earned by banks is liable to be taxed in GST. Further according to Schedule III, which describes activities or transactions should not be treated as supply of goods and services. So, No exemption is provided to any banking services. The Indian GST law should make clear whether the ambit of GST includes or excludes the interest on GST.

- Inter sale as well as Purchase of Foreign currency by banks or authorized dealers of foreign exchange are liable to be taxed in GST since no exemption is provided.

- Services by RBI are liable to be taxed in GST since no exemption is provided to them also.

- As GST is considered a supply tax regime, so for every kind of transaction, banks should determine the place of consumption and payment of GST.

- GST increases the cost of capital as under GST 50 per cent of CENVAT is charged which is then reversed, reducing credit of about 50 percent.

\section{CHALLENGES FACED BY BANKS IN GST IMPLEMENTATION}

\section{Registration process:}

Before the GST implementation, all the banks and other financial institutions had a centralized registration no matter in which state they work but due to GST all banks and other financial institutions have to register themselves separately for every state they work in. It has now become a mandatory for all banks to complete this process due to which banks face operational burden as they have to undergo a long legal registration process for every state they operate in.

2. Between branch transactions:

Before the advent of GST banks were not charged any tax for interstate transactions between two branches of same bank but after GST implementation banks are charged IGST i.e. integrated goods and service tax. Now transactions between two branches of same bank in different state are subject to GST. Generally, all banks are interconnected with their branches and share a lot in common like resolving customer relations, call centre, etc but due to GST implementation they are charged for it resulting in pointless cost hardships.

3. Banking service supply location.

Many a times, a customer has multiple accounts under same customer ID. It can have same address under different branches with different states. Thus, it may happen that the GST is paid in wrong state on the basis of "address on record basis". Banks has to take care that GST is paid to the respective state government.

\section{Charges on banking services}

GST is charged on all services except for deposits. Customers have to pay GST included in charges for ATM transactions, usage of cheque books etc. Loans are been charged 18 per cent GST. The concern is that earlier home loan was 8.5 per cent which was quite reasonable. Also, the investment in mutual funds is getting affected because of increased expenses. Insurance has become expensive with rise in premium as tax rate has increased from 15 to 18 per cent. Other facilities like lockers, billing, shopping has become more expensive as tax has increased by 3 per cent.

Table 1: Impact of GST implementation on banks

\begin{tabular}{|l|l|}
\hline Advantages & Benefits \\
\hline Self-regulatory taxation system & $\begin{array}{l}\text { Easily understandable to general } \\
\text { public }\end{array}$ \\
\hline Transparency & No confusion in tax filing and tax \\
\hline
\end{tabular}

\begin{tabular}{|l|l|}
\hline & rate \\
\hline Uniform taxation rate & No tax on deposit \\
\hline Mandatory registration for GST & $\begin{array}{l}\text { Increased the number of online } \\
\text { banking }\end{array}$ \\
\hline & $\begin{array}{l}\text { Registration under GST will } \\
\text { reduce the amount on tax payable } \\
\text { on the purchase of goods }\end{array}$ \\
\hline
\end{tabular}

Table 1 shows the advantages of GST model to banks and resultant benefits to customers

Table 2: Disadvantages of GST to banks and resultant constraints to customers

\begin{tabular}{|l|l|}
\hline Disadvantages & Constraints \\
\hline $\begin{array}{l}\text { Tax has raised to 18 per cent from } \\
15 \text { per cent }\end{array}$ & Costlier banking for customers. \\
\hline $\begin{array}{l}\text { Loan interest charged @ 18 per } \\
\text { cent. }\end{array}$ & $\begin{array}{l}\text { Customers are charged 18 per cent } \\
\text { on home loan, which was 8.5 per cent } \\
\text { earlier. }\end{array}$ \\
\hline $\begin{array}{l}\text { Place for banks to supply is not } \\
\text { specified. }\end{array}$ & $\begin{array}{l}\text { In banking, place of supply of service } \\
\text { shall be the location of the customer } \\
\text { on records }\end{array}$ \\
\hline $\begin{array}{l}\text { Multiple auditing is required as } \\
\text { state wise registration is } \\
\text { mandatory. }\end{array}$ & $\begin{array}{l}\text { Difficult for the bank to cope up with } \\
\text { the changes in registration because of } \\
\text { the presence of the bank in each } \\
\text { locality. }\end{array}$ \\
\hline $\begin{array}{l}\text { Interstate transactions between } \\
\text { two branches of bank are subject } \\
\text { to tax. }\end{array}$ & $\begin{array}{l}\text { It is expensive and inconvenient task } \\
\text { for the banks that each transaction } \\
\text { between the branches of the same } \\
\text { banks are attracted by IGST. }\end{array}$ \\
\hline
\end{tabular}

Table 2 shows the disadvantages of GST to banks and resultant constraints to customers.

\section{FINDINGS AND CONCLUSION}

The GST system is restructured so as to simplify current indirect Tax system in India. At the time of implementation of GST, all the sectors were facing many difficulties. But this system will help to improve the current taxation system and will further help to reduce the inefficiencies in the present taxation system. This will provide various advantages like unified tax system, reduced complaints and complexities, etc. The end consumer will find its cost a bit higher than before but it will remove all the discrepancies. The banks will also face a higher cost due to mandatory registration and inter-state goods and service tax. . The impact of GST on Banks seems to be such that operations of banks, transactions of banks, accounting and compliance should be reconsidered in its totality and ultimately, there is need for more analytical based research for successful implementation.

\section{REFERENCES}

1. Mujalde, S., Vani, A. (2017). Goods and Service Tax (GST) and its outcome in India. Journal of Madhya Pradesh Economic Association, 27(1), $1-4$.

2. Tewari, V. K. (2018). Goods and Service Tax. GST Simplified Tax System: Challenges and Remedies, 1(1), 173

3. Yadav, S. S., Shankar, R. (2018). Goods and service tax (GST): how and why. Journal of Advances in Management Research, 15(1), 2-3.

4. Banerjee, S., Agrawal, P. (2018). Impact of Goods and Service Tax after Implementation. Global Journal of Management and Business Research, 18(2), 1-6.

5. Bedi, Balwinder., Kavish, Sharma (2017). Moving to goods and service tax in India: Impact on India's growth. International Journal of Engineering Research \& Management Technology, 4(3), 120-128.

6. Article on "Impact of GST On the Banking Sector in India" published in gsthelplineindia.com on 09-10-2017.

7. Article on "The impact of GST on banking transactions, Insurance and Investments." published in www.equitymaster.com dated on 11- 07-2017 